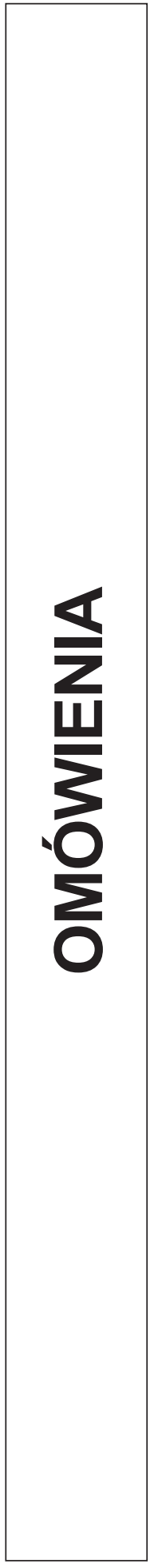





\section{WOJNA Z TERRORYZMEM ZA POMOCĄ DRONÓW}

Bardzo trudno jest ocenić skuteczność operacji bojowych z użyciem dronów ${ }^{1}$, które otacza nimb tajemnicy. W samym tylko Pakistanie, gdzie Stany Zjednoczone wykorzystują drony do ataków z powietrza na kryjówki i obozy szkoleniowe terrorystów islamskich zginęło w wyniku tych ataków w latach 2004-2012 od 2,5 do 3,3 tys. osób, w tej liczbie 400-900 cywilów (z czego 200 osób stanowiły dzieci). Są to jednak dane niepełne, które nie uwzględniają pewnej liczby ataków z użyciem dronów na terenach przygranicznych między Pakistanem i Afganistanem (Bergen, Tiedemann, 2010: 3-4). Należy zaznaczyć, że zarówno w Pakistanie i Afganistanie, jak również w Iraku, Jemenie i Somalii władze USA powierzyły prowadzenie operacji bojowych z użyciem dronów podmiotowi cywilnemu, tj. Centralnej Agencji Wywiadowczej. Jest to o tyle wygodne rozwiązanie, gdyż CIA nie musi przestrzegać regulacji obowiązujących siły zbrojne w kwestii użycia siły i sposobu realizacji wyznaczonych celów. Jednak udział cywilnej agencji wywiadowczej, jaką jest CIA, powoduje także liczne kontrowersje odnośnie „stopnia” legalności akcji bojowych realizowanych za pomocą dronów. Spory te dotyczą głównie niezbyt precyzyjnych norm prawno-międzynarodowych, które regulują użycie przez siły zbrojne USA i innych państw dronów, nie tylko w obecnej „globalnej wojnie” z terroryzmem.

\section{GENEZA I MOŻLIWOŚCI TECHNICZNE DRONÓW WOJSKOWYCH}

Balony bez załogi wypełnione środkami wybuchowymi pojawiły się w konfliktach zbrojnych już w połowie XIX w. Prace nad bardziej zaawansowanymi technicznie bezzałogowcami podjęto dopiero w czasie II wojny światowej w Niemczech. Natomiast po zakończeniu wojny prace te były kontynuowane w Stanach Zjednoczonych. Uległy one znacznej intensyfikacji po zestrzeleniu 1 maja nad ZSRR amerykańskiego samolotu szpiegowskiego (Zaloga, 2008; Singer, 2009: 32-36). Niektórzy autorzy wskazują już na lata 1916-1918, w których podjęto pierwsze próby konstrukcji bezzałogowych, wojskowych pojazdów latających. Jednak znaczący rozwój tej nowej broni nastąpił dopiero w ostatnich 30 latach drugiej połowy ubiegłego stulecia. W tym czasie, w wyniku rewolucji informatycznej bardzo znacznie przyspieszono $\mathrm{B}+\mathrm{R}$ nad produkcją UAV-ów, wyposażonych w samodzielny napęd, zdalnie sterowanych lub samosterujących i co wyróżnia je od pocisków kierowanych, nadających się do wielokrotnego użycia, czyli zdolnych do powrotu z misji do miejsca startu lub innego, uprzednio wyznaczonego, lądowiska. Od końca lat 80. XX wieku ulepszano techniczne właściwości

${ }^{1}$ Z języka angielskiego: Unmanned Aerian Vehicles (UAV), bezzałogowe pojazdy latające (bezzałogowce), potocznie nazywane dronami (od ang. drone oznaczającego brzęczenie lub warkot samolotu). 
UAV-ów. Najbardziej technicznie zaawansowane drony mają obecnie o wiele większy zasięg, udźwig, prędkość i czas przebywania w powietrzu niż pierwsze UAV-y, które były wykorzystane początkowo głównie do celów rozpoznawczo-wywiadowczych. W 1985 r. pierwszy dron Pioneer, wyprodukowany w kooperacji izraelsko-amerykańskiej, został wykorzystany w akcji bojowej w Libanie (Sching, 2007: 6). Dron ten miał zasięg tylko 100 mil morskich, natomiast wprowadzony dziesięć lat później do użytku amerykański UAV RQ-1 Predator (pol. Drapieżnik) miał już zasięg pięciokrotnie większy. Został on wprowadzony do wyposażenia amerykańskiej armii i sprawdził się znakomicie w trakcie interwencji NATO w Bośni i Kosowie (Cordesmann, 2003). Od początku XXI stulecia przyspieszono w USA prace nad produkcją dronów najnowszej generacji. Już w 2001 r. wprowadzono do użytku nowego drona $M Q-1$, który mógł przenosić pociski rakietowe powietrze-ziemia Hellifire, co nadało temu aparatowi charakter pojazdu bojowego (ang. Unmanned Combat Aerial Vehicle - UCAV). Zintensyfikowano także prace nad nowymi typami UAV-ów. Pojawił się wtedy m.in. większy, sprawniejszy i lepiej uzbrojony UCAV MQ-9 Reaper (pol. Żniwiarz) oraz największy tego typu pojazd Global Hawk RQ-4 o wielkości średniego odrzutowca pasażerskiego, który może bez przerwy latać całą dobę na wysokości 20 kilometrów i ma zasięg 5400 mil morskich (Gertler, 2012: 37).

Stany Zjednoczone i Izrael od wielu lat przodują w produkcji UAV-ów. Ten pierwszy kraj posiada też najwięcej na świecie wojskowych dronów. W 2003 r. Stany Zjednoczone posiadały kilkaset, głównie mniejszych dronów wojskowych, ale na początku $2014 \mathrm{r}$. miały takich pojazdów już prawie 10 tys., w tej liczbie kilkadziesiąt największych UAVów, których nie posiadają armie innych państw (zob. rys. 1). Od kilku już dekad drony wykorzystywane są do realizacji różnych zadań. W ostatnich latach nowością było to, że dzięki Globalnemu Systemowi Namierzania Celów (GPS) można dokładnie ustalić miejsca, w których znajdował się dron i precyzyjnie wykorzystać przesłane z niego, poprzez połączenie z różnych satelitów, informacje do danej bazy wojskowej czy nawet dowolnego oddziału przygotowującego się do ataku na wyznaczony cel. Przykładowo za pomocą informacji dostarczonych „błyskawicznie” przez drona latającego nad wyznaczonym terenem można sprawdzić, co znajduje się po drugiej stronie budynku, który ma zaatakować i opanować pluton komandosów. Takie informacje są na polu walki bezcenne i pozwalają zminimalizować ryzyko strat w żołnierzach biorących udział w danej akcji. Należy zaznaczyć, że amerykańskie UAV-y korzystają z pomocy, nie tylko wojskowych, lecz także z komercyjnych satelitów, w tym szczególnie tych, które mają „niestabilne” orbity. Taka sytuacja miała miejsce w listopadzie i grudniu 2013 r., kiedy to amerykańskie drony MQ-1 Predator i MQ-9 Reaper wykonywały swoje liczne misje bojowe korzystając z takich komercyjnych satelitów. Satelity te, najczęściej przez oszczędność paliwa (lub jego brak) nie mogą się utrzymać w ściśle określonym położeniu geostacjonarnym. Testy prowadzone w $2013 \mathrm{r}$. z wykorzystaniem bezzałogowych samolotów MQ-1 i MQ-9 pokazały, że anteny systemu łączności satelitarnej tych dronów mogą współpracować z takimi, tańszymi satelitami komunikacyjnymi, znajdującymi się na tzw. inclined orbit (pol. niestabilnych orbitach) odszukując je i śledząc przez cały czas prowadzenia misji. Właśnie takie satelity o „niestabilnych” orbitach stanowią problem dla użytkowników komercyjnych, ponieważ muszą mieć systemy z antenami ,śledzącymi”. „Niestabilne” satelity mają jednak swój plus, ponieważ ich właściciele oferują 
mniejsze ceny za wynajęcie kanału łączności w porównaniu do właścicieli satelitów ze stale korygowaną pozycją. Okazało się, że nowe oprogramowanie zastosowane w dronach MQ-1 i MQ-9, które są wykorzystywane do prowadzenia rozpoznania oraz wykonywania precyzyjnych uderzeń rakietowych i bombowych, umożliwia im korzystanie z satelitów komercyjnych, co daje spore oszczędności. Według niektórych szacunków koszt wynajęcia kanału łączności satelitarnej z wykorzystaniem inclined orbit satellite jest o $50 \%$ mniejszy niż przy systemach o precyzyjnie utrzymywanej pozycji (UASF, 2014: 1).

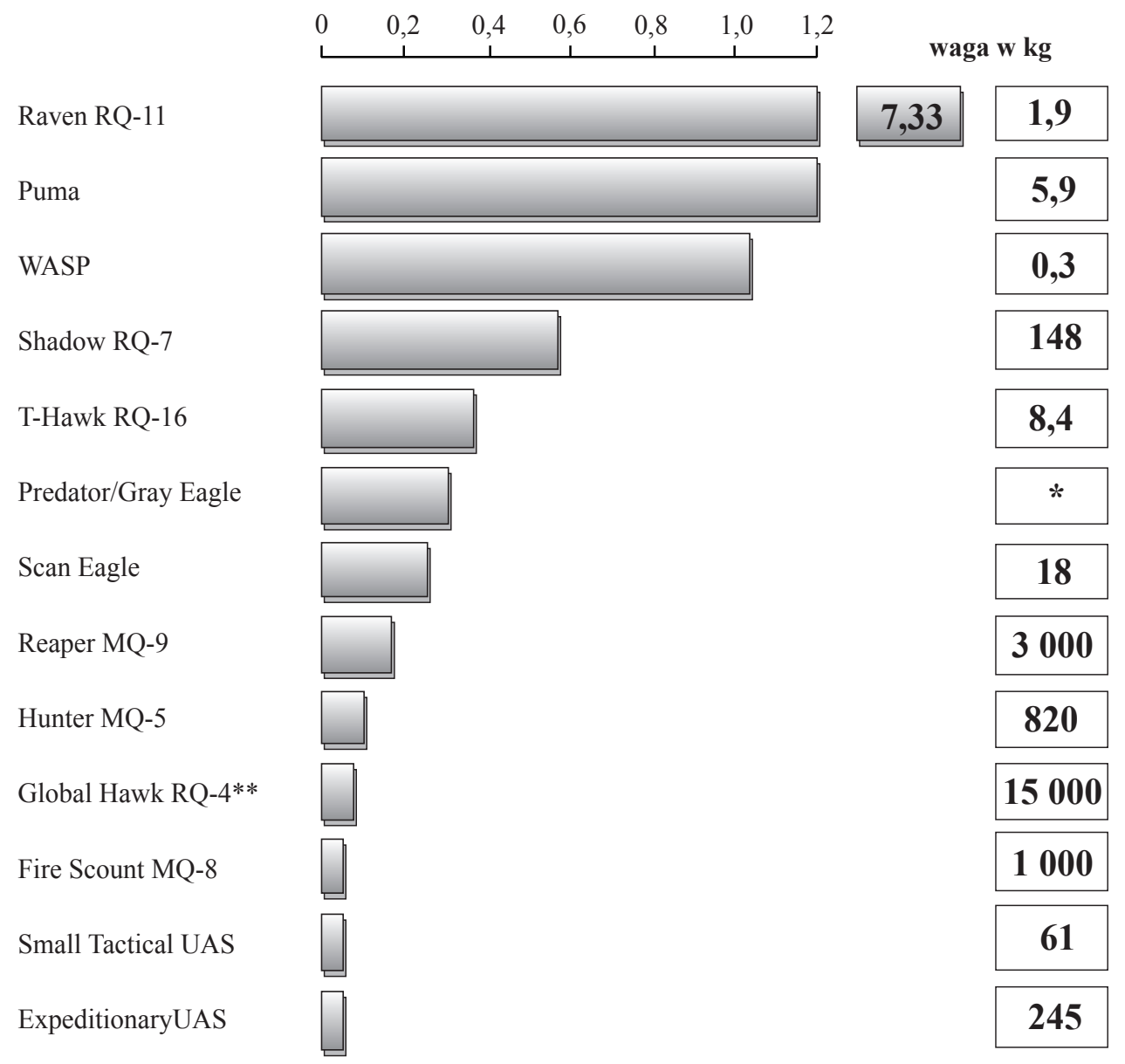

Rys. 1. Amerykańskie wojskowe drony w 2013 r. w tysiącach sztuk

* - Predator - 1000 kg, Gray Eagle - $1910 \mathrm{~kg}$.

** - Największy dron Global Hawk (Globalny Jastrząb) wykorzystywany m.in. do morskiego zwiadu jest największym bezzałogowcem o wielkości średniego odrzutowca pasażerskiego o 40-metrowej rozpiętości skrzydeł. Ten bezzałogowiec ma zasięg 5400 mil morskich, może dolecieć do każdego miejsca na Ziemi. Może też latać na wysokości $20 \mathrm{~km}$ przez ponad dobę. Global Hawk należy też do najdroższych dronów. Jego cena wynosiła w 2012 r. 141 mln dolarów. Zob.: Gertler, 2012: 36-39. Por.: Schwing, 2007: 6-10.

Źródlo: US Department of Defence i „The Economist” (2014), Special Report „Robots”, No. 13: 9. 
Jest rzeczą charakterystyczną, że w ciągu ostatnich paru dekad żaden amerykański dron ani też inny robot, mogący być wykorzystywany na polu walki jako zautomatyzowana broń, nie przeszedł pełnego procesu kwalifikacyjnego, jaki jest wymagany dla każdego rodzaju broni przed wprowadzeniem jej do użycia. Władze USA, a także innych państw okazują się bardzo liberalne w odniesieniu do zautomatyzowanej broni i przymykają oko na nieprzestrzeganie procedur związanych z ich testowaniem i w przypadku dronów zezwoliły na ich użycie w akcjach bojowych w różnych państwach. Trzeba jednak przyznać, że jeszcze stosunkowo mała część dronów wojskowych, uzbrojonych w rakiety i różne bomby, jak np. MQ-9 Reaper uzbrojony w rakiety przeciwpancerne, bierze udział w akcjach na polu walki. Większość tych ataków miała i nadal ma charakter precyzyjnych uderzeń na kryjówki terrorystów m.in. w takich państwach jak Pakistan, Jemen i Somalia, z którymi Stany Zjednoczone nie są w stanie wojny. Ataki te przeprowadzone były w ogromnej większości przez CIA, a nie przez amerykańską armię. Obecnie więc stosunkowo niewielka liczba dronów uzbrojonych w rakiety umożliwia Stanom Zjednoczonym prowadzenie skuteczniejszej strategii w globalnej wojnie z terroryzmem. Decyzje odnośnie tego kogo i gdzie zaatakować podejmowane są nie zawsze na najwyższym szczeblu, tj. przez prezydenta, lecz najczęściej na niższym szczeblu „urzędniczym” w gronie czołowych funkcjonariuszy CIA. Natomiast ,piloci” tych bezzałogowców siedzą wygodnie w odległej od miejsca ataku bazie i tylko naciskają w wyznaczonym momencie na „spust”. Trudno byłoby wskazać na inny wynalazek techniczny, o raczej niewielkim znaczeniu, który, tak jak drony, ma poważne konsekwencje nie tylko w sferze militarnej. Ta nowa broń jest przy tym relatywnie tania, gdyż nakłady na produkcję dronów są porównywalne z kosztami produkcji nowoczesnej broni konwencjonalnej. Natomiast ich efekty działania są nieporównywalnie wysokie. Przy obecnym stanie technologii trudno też z odpowiednim „wyprzedzeniem” wykryć nadlatującego drona. Stąd też budzą one grozę nie tylko wśród islamskich terrorystów, którzy najczęściej są przedmiotem ich ataków. Przykładowo w latach 2008-2013 Stany Zjednoczone wyeliminowały za pomocą dronów ponad 3300 terrorystów islamskich, członków Al-Kaidy i innych ugrupowań terrorystycznych działających w Pakistanie i Jemenie. W tej grupie było co najmniej 50 wysokich rangą przywódców Al-Kaidy i Talibów, których nie można było łatwo zastąpić innymi. Tym, m.in., można także tłumaczyć fakt „przyhamowania” w ostatnich kilku latach działalności terrorystycznej Al-Kaidy (Gwiazda, 2013b). Natomiast okresowe zaniechanie ataków dronami na bazy dżihadystów z tzw. Państwa Islamskiego było jedną z przyczyn ekspansji tego państwa na terenach północnego Iraku.

\section{UPOWSZECHNIENIE WOJSKOWYCH DRONÓW}

Intensyfikacja walki z terrorystami za pomocą dronów nastapiła na początku bieżącego stulecia, kiedy po zamachach z 11 września 2001 r. USA korzystały z szerokiego międzynarodowego poparcia dla nowej strategii globalnej wojny z terroryzmem. W miarę coraz większego wykorzystywania dronów bojowych przez USA i Izrael oraz Wielką Brytanię także wiele innych państw opracowało bądź kupilo odpowied- 
nie technologie i przystąpiło do wyposażenia swoich armii w zwiadowcze i bojowe drony. Państwa te dysponują najbardziej zaawansowanymi technologiami umożliwiającymi im budowę dronów, także wiele innych państw opracowało bądź kupiło odpowiednie technologie i przystąpiło do wyposażenia swoich armii w zwiadowcze i bojowe drony. Stworzyło to nową sytuację określaną przez niektórych ekspertów mianem nowego wyścigu zbrojeń, tym razem z dronami (a nie z bronią atomową) w roli głównej. Faktem jest, że w 2004 r. tylko 41 państw posiadało drony różnego rodzaju i przeznaczenia, natomiast w 2011 r. liczba tych państw wzrosła do 76, a przy końcu 2013 r. przekroczyła 80. Jednak do 2010 r. 90\% światowych wydatków na produkcję i utrzymanie dronów przypadało na USA, natomiast w 2013 r. udział tego mocarstwa zmniejszył się już do 64\% (Kreps, Zenko, 2014: 72). Należy podkreślić, że do początku 2014 r. wojskowe drony w stanie gotowości bojowej posiadały oprócz USA, Izraela i Wielkiej Brytanii jeszcze tylko ChRL i Iran. W listopadzie 2012 r. trakcie Międzynarodowej Wystawy Lotniczej w Zhuhai ChRL zaprezentowała drona wojskowego Wing Loong, który był uderzająco podobny do najbardziej technologicznie zaawansowanego, amerykańskiego Reapera. Z roku na rok Państwo Środka zwiększa nakłady na produkcję wojskowych dronów. Szacuje się, że chińskie wydatki na ten cel będą w 2020 r. takie same jak amerykańskie. Największe obawy USA, a także Japonii i innych państw wzbudza budowa chińskiego superdrona, na którego temat ChRL nie udostępnia szczegółowych informacji. Zdaniem amerykańskich ekspertów z Departamentu Obrony, którzy tego superdrona określili mianem Mrocznego Miecza (Dark Sword), jest to rozwijający zawrotne prędkości bezzałogowy statek powietrzny, który ma służyć zarówno do misji zwiadowczych, jak i do przeprowadzania ataków rakietowych. Chiński superdron ma być prawie niewykrywalny przez radary. Kształt skrzydeł i sposób budowy pozwalają przypuszczać, że ma zasięg kilku tysięcy kilometrów. Nie wiadomo, jak zaawansowane są prace na tą nowoczesną maszyną. Na początku $2014 \mathrm{r}$. Chińczycy zaczęli już budować lotniska dla dronów wzdłuż swojego wybrzeża. Także Rosja prowadzi intensywne prace nad prototypem swojego dużego drona wojskowego, który ma być gotowy pod koniec 2014 r. Władze Rosji chcą być w 2020 r. w pełni gotowe do używania dronów do celów bojowych. Inne państwa nie ujawniają planów wykorzystywania w najbliższej przyszłości dronów do celów bojowych. Szacuje się, że przy końcu 2013 r. ponad 78 państw dysponowało dronami różnej klasy (mniej lub bardziej nowoczesnymi). Najbardziej nowoczesne są w posiadaniu USA, które przez zakazy eksportu technologii UAV-ów chronią swój monopol w tej dziedzinie. Zakaz eksportu tej technologii nie obejmuje tylko Wielkiej Brytanii i Włoch. Natomiast Iran od dwóch lat posiada niewielką (nieujawnioną) liczbę wojskowych dronów o zasięgu do $2000 \mathrm{~km}$. Irańskie drony wojskowe mogą więc, praktycznie rzecz biorąc, prowadzić różnego rodzaju akcje wywiadowcze i bojowe na obszarze całego Bliskiego Wschodu. Kolejne sześć państw takich jak Indie, Pakistan, Turcja, Japonia, Australia i Singapur posiadają już odpowiednie technologie umożliwiające im produkcję wojskowych dronów. Indie moga z łatwością dozbroić posiadane przez siebie drony w systemy rakietowe, a Turcja zbudowała już około 24 dronów wojskowych przypominających amerykańskiego Reapera, po tym jak w ubiegłym roku Stany Zjednoczone nie zgodziły się na sprzedaż wojskowych dronów temu państwu, które jest przecież członkiem NATO. Natomiast Australia i Singapur opracowały własne konstrukcje dronów 
zwiadowczych, które wykorzystują do śledzenia ruchu chińskich okrętów w spornych regionach Morza Południowochińskiego, m.in. wokół archipelagu wysp Senkaku/Diaoyu. W ostatnich kilku latach także poszczególne państwa europejskie takie jak Francja, Wielka Brytania, Włochy i Niemcy zintensyfikowały prace nad produkcją dużych dronów wojskowych. Francuski koncern Dessault podjął intensywne prace nad konstrukcją dużych dronów już w $2003 \mathrm{r}$. w ramach projektu $n$-EUROn. W projekcie tym biorą udział także firmy z Włoch, Szwecji, Hiszpanii, Grecji i neutralnej Szwajcarii. Prototyp europejskiego dużego wojskowego drona został przetestowany $\mathrm{w}$ grudniu 2012 r., z kolei Wielka Brytania przetestowała w tym samym czasie swojego dużego drona wojskowego Taranis w Australii, ponieważ obowiązujące w tym kraju zasady dotyczące lotnictwa cywilnego zabraniają lotów dronami w cywilnej przestrzeni powietrznej. Natomiast Niemcy zdecydowały się najpierw na produkcję u siebie amerykańskiego drona Global Hawk wytwarzanego przez korporację Northrop Grumman. Zakup licencji i inne wydatki związane $\mathrm{z}$ budową tego drona miały kosztować podatnika niemieckiego 1 mld euro (1,36 mld dolarów). Jednak po stwierdzeniu, że nie będzie można na ten dron uzyskać odpowiedniego certyfikatu uprawniającego do latania w Europie, Niemcy wycofały się z planów budowy tego „globalnego" drona. Przy końcu 2013 r. armia niemiecka posiadała na swoim stanie zakupione w USA 3 duże drony wojskowe, a Francja miała 4 własnej produkcji, Włochy 9, Wielka Brytania 10, a USA aż 429 (Michaels, 2013: 18). Pomimo rosnącej, na całym świecie, „mody” na drony, do czego przyczyniła się w walnym stopniu polityka prezydenta Baracka Obamy, władze Niemiec dosyć ostrożnie podchodzą do budowy i wprowadzania do użytku dużych dronów wojskowych. W połowie 2013 r. Bundeswehra dysponowala 626 dronami. Wszystkie te bezzałogowce wykonują wyłącznie zadania zwiadowcze i nie są uzbrojone. Większość z nich to małe maszyny typu Aladin lub Mikado - ważą mniej niż $5 \mathrm{~kg}$ i są wykorzystywane do zwiadu taktycznego. Armia posiada także 53 aparaty KZO (niem. Kleinflugzeug für Zielortung, pol. mały samolot wskazujący cele) produkcji niemieckiej spółki należącej do Rheinmetall $A G$, trzy izraelskie samoloty Heron-1 oraz 96 dronów typu Luna ${ }^{10}$. Należy zaznaczyć, że nie powiodła się próba zbudowania dużego drona Euro Hawk. Pierwszy prototyp testowany w 2011 r. nie sprawdził się w kilku próbnych latach. Kontrolerzy stracili z nim kontakt, kiedy zboczył z wytyczonej trasy i niebezpiecznie obniżył wysokość. Dodatkowe koszty związane z wprowadzeniem do użycia Euro Hawka to około $600 \mathrm{mln}$ euro, jakie trzeba by wydać na same pozwolenia na jego loty w Europie. Z kolei władze USA wydały zakaz lotów dla Euro Hawk na ich terytorium, tj. w amerykańskiej przestrzeni powietrznej, co w pewnym stopniu przesądziło o losie tego drogiego projektu. Należy dodać, że Bundeswehra straciła także wiele innych dronów w wyniku wypadków spowodowanych usterkami technicznymi, błędami w obsłudze czy też złymi warunkami pogodowymi. Żadne jednak oficjalne źródło rządu RFN nie podaje precyzyjnie ani liczby utraconych dronów, ani też czasu i miejsca tych „wypadków”. Według niektórych szacunków do połowy 2013 r. Bundeswehra straciła 124 spośród 871 wszystkich wykorzystywanych przez nią dronów (Opposition, 2013). Nie wiadomo jednak ile z tych 124 dronów zostało zdalnie zniszczonych, ponieważ miały wiele poważnych usterek i np. nie dolatywały do wyznaczonych celów lub lądowały w innych, od zaplanowanych, miejscach. Jednak Niemcy należą do wiodących dostawców technologii do produkcji dronów, 
chociaż same nie posiadają ich wersji wojskowych. Przykładowo bawarska firma EMT Penzberg, która skonstruowała bojowego drona Luna, eksportuje zarówno gotowe drony, jak i technologie do ich produkcji do takich państw jak Holandia, Norwegia, Pakistan i Arabia Saudyjska.

\section{KONTROWERSJE ZWIAZZANE Z WYKORZYSTANIEM WOJSKOWYCH DRONÓW}

Nie ulega wątpliwości, że uzbrojone w rakiety różnego typu wojskowe drony są bronią ofensywną. Wiele państw, w tym Niemcy, nie zezwalają na ich użycie na własnym terytorium. Tego rodzaju drony nie mogą zresztą latać także w przestrzeni powietrznej pozostałych państw europejskich. Wykorzystywanie dronów wojskowych, np. amerykańskiego MQ-1 Predatora szczególnie przydatnego do selektywnych zabójstw (ang. targeted killings) przywódców terrorystów i innych niebezpiecznych osób, z punktu widzenia bezpieczeństwa, niekoniecznie międzynarodowego, lecz najczęściej bezpieczeństwa USA w innych krajach wymaga „przyjaznego" tam środowiska. Jednak Reaper jest bardzo podatny na zestrzelenie. Stąd też pożądane jest zapewnienie pewnej ochrony wojskowym dronom latającym nad terytorium danego państwa lub przynajmniej tolerowania tego rodzaju lotów. Taką politykę prowadziły i nadal prowadzą, pomimo protestów znacznej części swoich obywateli, władze takich państw, jak Afganistan, Irak, Pakistan, Jemen i Somalia, gdzie najczęściej USA wykorzystują swoje drony do realizacji „selektywnych zabójstw”. Wielu autorów zajmujących się wykorzystywaniem dronów do celów bojowych wyraża opinię, że zabijanie za pomocą dronów poza ich udziałem w działaniach wojennych, bez formalnego wypowiedzenia wojny nie jest dozwolone w świetle prawa międzynarodowego (Khan, 2002: 31-33; Strawser, 2010: 342).

W literaturze fachowej można spotkać się z opiniami, które wskazują na niesprecyzowane normy prawno-międzynarodowe dotyczące statusu działań antyterrorystycznych. Takie niezbyt jasne normy mają rzekomo sprzyjać używaniu dronów do realizacji „selektywnych zabójstw” i innych zadań bojowych. Jak trafnie zauważył Janusz Symonides, dotychczasowe debaty w Radzie Praw Człowieka i na Zgromadzeniu Ogólnym ONZ potwierdziły fakt, że zdecydowana większość państw nie kwestionuje legalności wojskowych (uzbrojonych) dronów jako środka walki w czasie konfliktów zbrojnych. Natomiast duże kontrowersje wzbudza ich użycie do „selektywnego zabójstwa” (selektywnej eliminacji) poza obszarem konfliktów zbrojnych i w sytuacjach, w których ataki dronami powodują także straty wśród ludności cywilnej (Symonides, 2014: 24-25).

Zdaniem wielu ekspertów można dość precyzyjnie określić status prawny akcji dronów o charakterze bojowym na gruncie obowiązujących norm prawa międzynarodowego, w tym prawa humanitarnego konfliktów zbrojnych, a rozbieżności interpretacyjne wynikają nie ze specyfiki operacji z użyciem UAV-ów per se, lecz z możliwości różnej oceny kontekstu prawnego, w jakim się one odbywają. Tak więc w praktyce o legalności użycia dronów do celów bojowych oraz ich dopuszczalnych formach i sposobach przeprowadzenia danej akcji decyduje przede wszystkim to, czy są one podejmowane $\mathrm{w}$ toku konfliktu zbrojnego (międzynarodowego lub wewnętrznego) czy też nie (Madej, 2012: 66). Trudno nie zauważyć, że wykorzystywanie dronów do 
celów bojowych odbywało się dotychczas w ogromnej większości wypadków właśnie na obszarach objętych różnymi konfliktami zbrojnymi. Nie zawsze były to i są nadal precyzyjne ataki na wybrane cele, np. lokalnych przywódców Al-Kaidy i innych ugrupowań terrorystycznych. Przykładem mogą być ataki amerykańskich dronów przeprowadzone w połowie sierpnia $2013 \mathrm{r}$. w Jemenie, których celem miał być miejscowy przywódca Al-Kaidy (Wesołowska, 2013: 72). W tym przypadku, na skutek błędu operatora drona, wystrzelona z niego rakieta uderzyła w zupełnie inny samochód niż ten, w którym parę minut wcześniej przejechał tą samą drogą miejscowy przywódca Al-Kaidy. W rezultacie tej pomyłki zginęła niewinna rodzina, której krewni i znajomi dołączyli do coraz liczniejszego grona wrogów USA. Nie przekonują ich bowiem argumenty administracji Baracka Obamy, że drony są najlepszym narzędziem do zwalczania terrorystów i że nowa broń pozwala oszczędzać życie amerykańskich żołnierzy, skoro nie zawsze pozwala oszczędzić życie niewinnych cywilów. Nieoczekiwanym więc efektem ubocznym amerykańskiej wojny z terrorystami za pomocą dronów jest to, że tworzą one więcej wrogów niż ich zabijają. Po każdej bowiem śmierci niewinnych ludzi, którzy przypadkowo znaleźli się w pobliżu miejsca ataku drona, wzrasta poparcie dla Al-Kaidy. Wprawdzie rząd Jemenu wypłaca rodzinie zabitych cywilów odszkodowanie, ale nadal wspiera takie akcje antyterrorystyczne, gdyż uważa, że ataki za pomocą dronów są konieczne, aby wyeliminować Al-Kaidę, która stanowi zagrożenie nie tylko dla bezpieczeństwa tego kraju, lecz także dla bezpieczeństwa międzynarodowego. Natomiast jemeńscy obrońcy praw człowieka (i zresztą nie tylko oni) domagają się uznania ataków dronów za akty kryminalne. Ich zdaniem kuriozalna jest i przede wszystkim niezgodna z prawem sytuacja, w której przywódca państwa „upoważnia" przywódcę innego mocarstwa do zabijania własnych ludzi. Taka postawa i aktywne popieranie antyterrorystycznych operacji z użyciem amerykańskich dronów wojskowych narusza podstawowe, humanitarne zasady i wartości.

Największe kontrowersje budzą właśnie kwestie humanitarne i reguły prawno-polityczne, zgodnie z którymi Stany Zjednoczone przeprowadzają w różnych państwach akcje bojowe za pomocą dronów. Należy zaznaczyć, że w samych Stanach Zjednoczonych nie opublikowano odpowiedniego aktu prawnego, który regulowałby sprawę podejmowania decyzji o dokonaniu ,selektywnego zabójstwa” za pomocą drona. W centrali CIA opracowuje się ,na bieżąco” tylko „priorytetowe cele”, które zawierają listę kilkunastu lub czasami nawet kilkudziesięciu czołowych terrorystów. Taką „listę śmierci” podpisywał zatrudniony przez CIA radca prawny i jego podpis zwykle wystarczył, aby można było rozpocząć procedurę „wykonywania”, za pomocą drona, wydanego w ten sposób wyroku śmierci. Zdaniem Johna A. Rizzo prezydent USA nie przeglądał ani też nie zatwierdzał nazwisk wprowadzanych „listę śmierci”, a wyroki zapadały na wyższych szczeblach agencji CIA (McKevely, 2011: 21). W praktyce jednak obowiązują w tej dziedzinie procedury wypracowane za czasów administracji prezydenta George'a W. Busha. Zdaniem dziennikarzy śledczych „New York Times” zaufany współpracownik prezydenta John Brennan dostarcza prezydentowi Barackowi Obamie listę tych terrorystów, których należy za pomocą dronów, wyeliminować, a prezydent $\mathrm{z}$ reguły listę tę akceptuje. Tak było przynajmniej w przypadku wszystkich ataków amerykańskich dronów w Jemenie i Somalii oraz w przypadku jednej trzeciej tych ataków w Pakistanie (Becker, Shane, 2012: 1-2). Niezbyt jasne są też kryteria do- 
syć arbitralnego decydowania przez władze USA o użyciu wojskowych dronów. Niektóre, co prawda niezbyt liczne, ich ataki skierowane są wobec osób noszących broń, co jest np. w Jemenie zjawiskiem powszechnym i oczywiście ogromna większość tych uzbrojonych ,przechodniów” to nie są terroryści tylko zwykli obywatele posiadający karabin dla samoobrony. Ataki na takich przypadkowych ludzi noszących na ramieniu karabin powodują największą liczbę przypadkowych ofiar i są przedmiotem ostrej krytyki ze strony rządów tych państw, na terenie których miał miejsce dany atak oraz ze strony różnych organizacji międzynarodowych domagających się zaprzestania posługiwania się dronami do zabijania ,rzekomych” terrorystów. Ataki dronów na wszystkich uzbrojonych mężczyzn czy też na obozy zbuntowanych przeciwko lokalnym władzom partyzantów niewiele mają wspólnego z „,selektywnymi zabójstwami” czołowych terrorystów międzynarodowych. Są one raczej specyficzną formą wspierania przez USA niektórych swoich sojuszników, którzy sami nie potrafią sobie poradzić ze swoją opozycją i jej uzbrojonymi oddziałami partyzanckimi.

Usprawiedliwienie więc wykorzystania wojskowych dronów ich szczególną użytecznością w globalnej wojnie z międzynarodowym terroryzmem nie zawsze więc znajduje potwierdzenie w przeprowadzanych atakach. Spora część tych ataków skierowana jest nie na najgroźniejszych terrorystów, lecz także na inne cele. To ostatnie budzi coraz więcej kontrowersji, podobnie zresztąjak dotychczasowe procedury dosyć arbitralnego ustalania przez władze USA ,wyjątkowo niebezpiecznych terrorystów”, stanowiących zagrożenie dla amerykańskich interesów i bezpieczeństwa międzynarodowego (Currier, Elliott, 2013: 2). Należy dodać, że do selektywnej eliminacji kwalifikują się także obywatele amerykańscy, jak zabity w 2011 r. w Jemenie pociskiem wystrzelonym z drona duchowny Anwar al-Awlahawi, który należał do grona przywódców stowarzyszonej z Al-Kaidą organizacji terrorystycznej. Także selektywne zabójstwo obywatela amerykańskiego jest uzasadnione w sytuacji, w której zagraża on w sposób niepodlegający dyskusji Stanom Zjednoczonym i pozostaje nieuchwytny dla organów ścigania. Nietrudno zauważyć, że w sytuacji nie tyle tradycyjnego, międzynarodowego, ile transnarodowego konfliktu zbrojnego, za jaki administracja G. W. Busha uznała wojnę USA z Al-Kaidą na obszarze całego świata, amerykański prezydent ma wolną rękę w wyznaczaniu celów tych ataków. Łatwo można więc ominąc obowiązujące prawo międzynarodowe, które poza pewnymi wyjątkowymi okolicznościami (np. odbicie z rąk piratów porwanego na morzu statku) traktuje zabójstwo dokonane na polecenie władz państwa „w każdych warunkach jako nielegalne, albo przynajmniej moralnie i prawie watpliwe" (Madej, 2012: 68; Falk, 2013: 1-2). Jednak Amerykański Kongres upoważnił prezydenta w trakcie trwania ,transnarodowego" konfliktu zbrojnego z Al-Kaidą i innymi ugrupowaniami terrorystycznymi do „podjęcia wszystkich koniecznych i „odpowiednich” środków przeciwko tym ugrupowaniom" (Horowitz, 2014: 66). Nie określono też końca tego konfliktu. Nie była to data zabicia lidera Al-Kaidy Osamy bin-Ladena i wydaje się, że konflikt ten będzie „trwał” tak długo, jak długo będzie leżeć w interesie USA, które od kilku lat stosują inną, niż klasyczna, strategię wojskową dla realizacji swoich geostrategicznych celów. Polega ona właśnie na atakach na wyznaczone cele przez niewielkie oddziały komandosów lub przez wojskowe drony i inne roboty. Coraz częściej wojskowe drony atakują i zabijają nie tylko czołowych terrorystów, którzy planują i przygotowują zamach 
w USA lub innym państwie zachodnim, lecz także na somalijskich piratów, afgańskich Talibów i ostatnio także na dżihadystów z tzw. Państwa Islamskiego, a także na bazy partyzantów w różnych krajach świata.

Zdaniem przedstawicieli administracji amerykańskiej, tego rodzaju ataki uzasadnione są stanem ,permanentnej wojny” z terroryzmem, a taka wojna może tylko pogłębić problemy ogromnej większości krajów świata dążących do zaprowadzenia trwałego pokoju. Rzecz jasna zaprzestanie przez USA dokonywania ataków za pomocą wojskowych dronów wcale nie przybliży ery trwałego lub, jak to określił Immanuel Kant, „wiecznego” pokoju. Do tego potrzebna jest współpraca większości państw świata i można taki stan osiagnąc nie tyle za pomocą środków militarnych, ile przede wszystkim poprzez polityczne rozwiązanie wielu współczesnych problemów globalnych. Dlatego należy raczej dążyć do ograniczenia globalnego wymiaru wojny z terroryzmem oraz do skuteczniejszych działań zbrojnych i przede wszystkim dyplomatycznych w skali regionalnej i lokalnej.

Nie bardzo wiadomo czy do tego zmierza od pewnego czasu administracja Baracka Obamy, która zdaje sobie sprawę, że nie można traktować całego świata jako „pola bitwy" z terrorystami. Żyją oni bowiem i mają swoje bazy w konkretnych państwach, chociaż ich akcje zbrojne i zamachy przeprowadzane są w wielu innych państwach jak ostatnio zamachy we Francji, Danii i Tunezji. Walka terrorystów islamskich z resztą świata ma więc wymiar globalny, co zmusza poniekąd kraje zachodnie do podjęcia także globalnej wojny z terroryzmem. Ani Stany Zjednoczone ani też inne kraje zachodnie nie mogą sobie pozwolić w sytuacji narastającego zagrożenia ze strony tzw. Państwa Islamskiego na zaprzestanie posługiwania się „twardą siłą" militarną. Nie mogą więc posługiwać się tylko „miękką siłą”. Taka radykalna zmiana strategii walki nie tylko ze współczesnymi terrorystami, lecz także z wrogo nastawionymi do siebie państwami, jest z wielu względów niemożliwe i z pewnością samo posługiwanie się soft power nigdy nie doprowadziłoby do trwałego pokoju.

Kwestią dyskusyjną jest ocena posługiwania się przez USA dronami w walce z terroryzmem. Mogą one, praktycznie rzecz biorąc, uderzyć w każdy cel i w każdym zakątku świata na mocy arbitralnej decyzji prezydenta największego supermocarstwa. Należy zaznaczyć, że prezydent Barack Obama zobowiązał się na początku swojej pierwszej kadencji do „stałego” zwalczania „politycznych ekstremistów-terrorystów" wszędzie tam gdziekolwiek mają oni swoje bazy. Jednocześnie zobowiązał się do przestrzegania $\mathrm{w}$,globalnej wojnie" $\mathrm{z}$ terroryzmem obowiązującego prawa, norm etycznych i Konstytucji USA. Obiecał także szybkie opracowanie i wdrożenie przejrzystych zasad uniemożliwiających monitorowanie i rozliczanie każdej decyzji o ataku na każdy wyznaczony cel na „światowym polu bitwy z terrorystami”. Jednak w praktyce nie zawsze to się udaje.

Oczywiście nie jest to wina nowej technologii i rzekomo coraz bardziej ,,autonomicznych" wojskowych robotów, którymi są wojskowe drony. Trudno jest bowiem ustalić precyzyjnie reguły „nowej gry wojennej”, które jasno określiłyby kogo i dlaczego należy zabić za pomocą rakiety wystrzelonej z wojskowego drona i jak przy tym uniknąć strat wśród cywilów znajdujących się w pobliżu wyznaczonego celu. Bardzo trudno jest też oszacować, ile nowych wrogów przysparza USA każdy atak wojskowego drona i jak te ataki mają się do norm moralnych obowiązujących w „cy- 
wilizowanych" państwach zachodnich. Kwestią nierozstrzygniętą pozostaje sprawa swoistego „naginania” prawa międzynarodowego do realiów „nowej wojny” prowadzonej za pomocą wojskowych dronów. Czy można będzie jeszcze długo utrzymywać, że tego rodzaju wojna jest zgodna z obowiązującym prawem wojennym i międzynarodowym i z wyznaczonymi wartościami oraz obowiązującymi normami moralnymi? Wydaje się, że nie. Nowe technologie, nie tylko wojskowe, wymuszały w przeszłości i nadal wymuszają wprowadzanie w życie nowych regulacji prawnych. Nie zawsze jednak zastosowanie nowej technologii zbiega się w czasie z wprowadzeniem w życie, przygotowanych już a priori regulacji prawnych. Najczęściej jest zupełnie na odwrót. Zwykle też pojawienie się różnych, negatywnych efektów ubocznych, związanych z zastosowaniem nowej technologii powoduje przyśpieszenie prac nad opracowaniem nowych zasad posługiwania się nową technologią.

W przypadku wojskowych dronów najbardziej negatywnymi efektami ubocznymi, związanymi z ich zastosowaniem w obecnej globalnej wojnie z terroryzmem, jest relatywnie duża liczba ofiar wśród cywilów i związany ściśle z tym zjawiskiem wzrost liczby ludzi popierających terrorystów, a nie pomagających ich zwalczać. Coraz więcej ludzi w krajach zachodnich, w tym także w samych Stanach Zjednoczonych, kwestionuje, rzekomo humanitarną, broń, jaką są wojskowe drony i inne wojskowe roboty (Campaign, 2014). Zresztą ludzkość nigdy nie wymyśliła żadnej humanitarnej broni, bo wszystkie jej rodzaje służące do zabijania ludzi trudno nazwać „humanitarnymi”. Jeszcze większe sprzeciwy wywołuje kwestia arbitralnego, w praktyce tajnego, wyznaczania „selektywnych zabójstw”. Tajnego wobec wyznaczonego do likwidacji terrorysty, którego, jak w przypadku al-Awlahiego, uznano za przyszłe, poważne zagrożenie dla bezpieczeństwa USA i bezpieczeństwa międzynarodowego i dlatego skazano go ,zaocznie” na śmierć. Nie skazano go w jawnym procesie sądowym za zbrodnie, jakich ten terrorysta dopuścił się w przeszłości, lecz tylko na podstawie subiektywnej oceny przyszłego zagrożenia, jakie może grozić z jego strony. Tego rodzaju procedura wyznaczania ,selektywnych zabójstw” nie daje „wyznaczonemu celowi” czyli konkretnemu człowiekowi żadnego prawa do obrony i wykazania np. dowodów potwierdzających jego zerwanie z działalnością terrorystyczną. Trudno sobie wyobrazić sytuację, w której prezydent USA, w podobny sposób, jak ,zagranicznych” terrorystów, skazuje na śmierć w ramach tajnej procedury „,ukierunkowanych zabójstw” dowolnego Amerykanina, o którym jego służby wywiadowcze poinformowały go, że jest wrogiem swojego kraju ojczystego i stanowi dla niego ,poważne” zagrożenie.

Nie może więc dziwić fakt, że sporą część społeczności międzynarodowej coraz bardziej oburza stosowanie przez prezydenta USA uprawnień jedynego „sędziego” w stosunku do potencjalnych wrogów Ameryki i skazywanie ich, w ramach tajnego quasi sądowego procedowania, na śmierć. Istnieją duże obawy, że przywódcy innych państw, nie tylko autorytarni przywódcy, pójdą wkrótce za przykładem demokratycznego prezydenta USA i w miarę rozbudowy swojej floty wojskowych dronów także będą w podobny sposób arbitralnie skazywać na śmierć ,,swoich” wrogów zewnętrznych i wewnętrznych (np. przywódców ugrupowań partyzanckich, z którymi nie może sobie poradzić armia i policja). Trudno przewidzieć, w jaki sposób i w oparciu o jakie zasady będzie się dalej toczyć globalna wojna z terroryzmem za pomocą dronów. Z niektórych państw (np. z Iraku w 2013 r. i Afganistanu w 2014 r,), w których nie 
udało się pokonać islamskich terrorystów, Stany Zjednoczone i ich sojusznicy wycofały swoje wojska. Do innych państw żołnierze amerykańscy prawdopodobnie wkrótce powróca, chociaż w znacznie mniejszym kontyngencie, aby pomóc w pokonaniu dzihadystów z tzw. Państwa Islamskiego, z którymi nie potrafi sobie poradzić armia iracka. Zwiększa się bowiem, a nie zmniejsza liczba „niestabilnych”, chylących się ku upadkowi, państw, w których umacniają swoje wpływy różne ugrupowania terrorystyczne. Nie zabraknie więc pracy ani operatorom wojskowych dronów, ani też służbom wywiadowczym namierzającym poszczególne cele i przede wszystkim wąskiej grupie decydentów zlecających „selektywne zabójstwa” za pomocą, budzących coraz większą grozę, nie tylko wśród terrorystów, dronów. Jednak coraz powszechniejsze posługiwanie się wojskowymi dronami nie zapewni absolutnego bezpieczeństwa żadnemu państwu ani też nie przyczyni się do znaczniejszej poprawy bezpieczeństwa międzynarodowego. Można raczej założyć, że zmniejszy się poczucie bezpieczeństwa i jednocześnie zwiększy ryzyko wybuchu różnych zbrojnych konfliktów w skali regionalnej i lokalnej, szczególnie na spornych obszarach, gdzie nie ustalono, na mocy bilateralnych traktatów, dokładnych granic między poszczególnymi państwami. Dotyczy to szczególnie granic morskich. Takich „,spornych” granic morskich jest - zdaniem CIA - aż 430, z których większość nie została ściśle określona i uzgodniona na mocy formalnych porozumień zwartych pomiędzy graniczącymi ze sobą na morzu państwami. Przykładem może być spór ChRL i Japonii o wyspy Senkaku/Diaoyu, wokół których, od prawie roku, „krążą” chińskie drony (Gwiazda, 2013a: 81-84). Nie wiadomo, ile chińskich dronów zestrzeliły patrolujące ten rejon japońskie myśliwce. Wiadomo jednak, że o wiele łatwiej, w sensie uniknięcia potem poważniejszych konsekwencji, można podjać decyzję o zestrzeleniu bezzałogowego statku powietrznego, aniżeli klasycznego myśliwca czy samolotu szpiegowskiego. Przekonały się o tym także USA, kiedy w listopadzie 2012 r. irański myśliwiec otworzył ogień do amerykańskiego Predatora, który naruszył irańską przestrzeń powietrzną. Amerykanie stwierdzili po tym incydencie, że ich dron przelatywał nad wodami międzynarodowymi i wcale nie naruszył irańskiej przestrzeni powietrznej. Jednak nie podjęli wtedy żadnej akcji odwetowej, chociaż zagrozili Iranowi wprowadzeniem nowych sankcji. Zamiast jednak rozszerzenia sankcji Stany Zjednoczone dokonały w drugiej połowie 2013 r. radykalnej zmiany swojej polityki wobec Iranu i po zawarciu z tym państwem w lipcu $2015 \mathrm{r}$. trwałego porozumienia w sprawie ograniczenia przez Iran programu nuklearnego, rozpoczęły proces normalizacji stosunków politycznych i gospodarczych (Gwiazda, 2015: 219-221; Liebich, 2015: 1-2).

Trudno przewidzieć czy Iran w najbliższej przyszłości rzeczywiście zrezygnuje z rozwoju swojego programu wzbogacania uranu, który można wykorzystać także do budowy bomby atomowej. $Z$ pewnością wykorzysta okres najbliższych kilku lat po zniesieniu przez kraje zachodnie sankcji gospodarczych dla rozbudowy i modernizacji swoich arsenałów broni konwencjonalnej. Niedawno Iran zakupił w ChRL także pewną liczbę wojskowych dronów. Prowadzi także własne prace nad ich budową. Podobnie postępuje wiele innych państw świata. Wkrótce więc wojskowe drony mogą okazać się sporym, choć oczywiście w nieporównywalnie mniejszej skali, zagrożeniem dla bezpieczeństwa narodowego poszczególnych państw i bezpieczeństwa międzynarodowego, jak broń atomowa. Kwestia proliferacji tej nowej broni budzi obecnie 
większe obawy aniżeli kontrowersje związane z posługiwaniem się wojskowymi dronami dla eliminacji terrorystów, którzy często według arbitralnych ocen, mogą stanowić zagrożenie dla światowego pokoju. Niewątpliwie istnieje pilna potrzeba międzynarodowych regulacji określających zasady wykorzystywania wojskowych dronów w akcjach bojowych, w tym szczególnie dla realizacji „,selektywnych zabójstw”, jak również zmniejszenia tempa rozpowszechniania się nowej broni. W obecnej sytuacji geopolitycznej charakteryzującej się wybuchem nowych i zaostrzeniem starych konfliktów między poszczególnymi państwami szanse na zawarcie odpowiedniego, międzynarodowego porozumienia w tej sprawie są niestety niewielkie.

\section{BIBLIOGRAFIA}

Becker J., Shane S. (2012), Secret ,kill list” poses a test of Obama principles and will, http:/www.nytimes.com/2012/05/29/world/obamas-leadership-in-war-on=al-queda. html?pagewanted=all\&_r=0 (21.12.2015).

Bergen P., Tiedemann K. (2010), The Year of the drone: an analysis of U.S. drone strikes in Pakistan, 2004-2012. Counterterrorism Strategy Initiative Policy Paper, New American Foundation, 24.02.2010, http://venv.org/files/NAF_YearOfTheDrone.pdf (21.12.2015).

Campaign to Stop Killer Robots (2014), http://www.stopkillerrobots.org (17.05.2014).

Cordesmann J. A. (2003), The lessons and nonlessons of the air and missile campaign in Kosovo, 17.9.2003, http://csis.org/files/media/csis/pubs/kosovolessons-ful.pdf (14.03.2014).

Currier C., Elliott J. (2013), The drone war doctrine we still know nothing about, „Pro Publica”, 26.02.2013, http://www.propublica.org/article/drone-war-doctrine-we-know-nothing-about. (21.12.2015).

Drone wars (2015), (eds.) P. Bergen, I. D. Rothenberg, Tampa.

Falk R. (2013), Ending perpetual war? Endorsing drone warfare?, „Foreign Policy Journal”, 1.06.2013, http://www.foreignpolicyjournal.com/2013/06/01/ending-perpetual-war-endorsing-drone-warfare (18.05.2014).

Franke U. E. (2013), Verbreitung von unbemannten Flugzeugen fuer den militaerischen Gebrauch, „Aus Politik und Zeitgeschichte”, nf 37.

Gertler J. (2012), U.S. Unmanned aerial systems, CRS Report for the Congress, Washington.

Gwiazda A. (2015), Niepewna normalizacja stosunków polityczno-gospodarczych Iranu z Zachodem, „Przegląd Strategiczny”, nr 8.

Gwiazda A. (2013a), Archipelag niezgody, „Polska Zbrojna”, nr 12.

Gwiazda A. (2013b), Użyteczne, kontrowersyjne drony, portal „wpolityce.pl”, 9.08.2013, http:// wpolityce.pl/polityka/163834-uzyteczne-kontrowersyjne-drony-krytycy-poslugiwania-siedronami-w-walce-ze-wspolczesnym-terroryzmem-zwykle-nie-dostrzegaja-niewygodnychdla-siebie-faktow (18.05.2014).

Horowitz M. C. (2014), The looping robotics gap, ,Foreign Policy”, No. 6.

Khan P. (2002), The paradox of riskless warfare, „Philosophy and Public Policy Quarterly”, No. 3.

Kreps S., Zenko M. (2014), The next drone wars, ,Foreign Affairs”, March-April, No. 2.

Libront K. (2013), Niemiecka awantura o drony, portal „geopolityka.org” (29.06.2013).

Liebich D. (2015), Will the Iran nuclear deal change the geopolitics oft he Middle East?, „Foreign Policy Journal”, 8.09.2015, http://www.foreignpolicyjournal.com/2015/09/08/will-the-irannuclear-deal-change-the-geopolitics-of-the-middle-east/ (21.12.2015). 
Madej M. (2012), Drone war on terrorism - użycie bezzałogowych pojazdów latajacych (UAV) $w$ walce z terroryzmem, „Polski Przegląd Dyplomatyczny”, nr 3.

McKevely T. (2011), Inside the killing machine, „Newsweek” 13.02.2011.

Michaels D. (2013), Europe's push into drones remains elusive, „The Wall Street Journal”, 9.10.2013.

Opposition wirft Ministerium Vertuschung vor (2013), „Frankfurter Allgemeine Politik”, 10.06.2013, http://www.faz.net/aktuell/politik/Island/drohnen-affaere-opposition-wirft-ministerium-vertuschung-vor-122116437.html (1.12.2015).

Rokita J. (2013), Lista Obamy czyli o klopotach polityki celowanych zabójstw, „Horyzonty Polityki”, nr 6.

Sching R. (2007), Unmanned aerial vehicles: revolutionary tools in war and peace, USAWC, Carlile Barracks.

Singer P. W. (2009), Wired for war. The robotics resolution and conflict in the 21st century, New York.

Strawser B. J. (2010), Moral predators, „Journal of Military Ethics”, Vol. 9, Issue 4.

Symonides J. (2014), Prawnomiędzynarodowe problemy użycia dronów w walce z terroryzmem. Debaty $i$ kontrowersje, „Bellona”, $\mathrm{nr} 4$.

USAF: Bojowe misje bezzałogowców w oparciu o niestabilne satelity (2014), portal „defence24”, 6.02.2014, http://www.defence24.pl/55266, usaf-bojowe-misje-bezzalogowcow-w-oparciuo-niestabilne-satelity (28.04.2014).

Watts J. (2013), Technology game changers, „The Futurist”, July-August, No. 4, s. 20-24.

Wesołowska E. (2013), Jemen - punkt zapalny, „Angora”, 18.08.2013.

Zaloga S. (2008), Unmanned aerial vehicles, robotic air warfare 1917-2007, Oxford.

\title{
STRESZCZENIE
}

Coraz powszechniejsze wykorzystywanie w operacjach bojowych bezzałogowych statków powietrznych, nazywanych potocznie dronami wzbudza wiele kontrowersji. Paradoksem jest fakt, że mniejsze kontrowersje międzynarodowe wywołuje zjawisko stosunkowo szybkiego upowszechniania się UAV-ów w siłach zbrojnych wielu państw, jak również coraz powszechniejsze ich wykorzystywanie przez różne firmy prywatne, w tej liczbie także prywatne formy wojskowe (PMC). Jednak największe spory dotyczą posługiwania się przez Stany Zjednoczone dronami w walce z terroryzmem. Spory te koncentrują się szczególnie wokół dopuszczalności takich operacji bojowych poza obszarem konfliktów zbrojnych i ich statusu prawnego oraz ich efektywności militarnej w porównaniu do uzyskanych rezultatów, w tym także tzw. efektów ubocznych, czyli liczby zabitych cywilów - którzy nie byli celem danej operacji antyterrorystycznej, określonej mianem „selektywnego zabójstwa” (ang. targeted killing). Artykuł omawia rozwój i możliwości techniczne różnych rodzajów wojskowych dronów, ich wykorzystywanie w operacjach antyterrorystycznych oraz ryzyko związane z szybką proliferacją tej nowej broni.

Słowa kluczowe: wojskowe drony (UAV), „listy śmierci”, strategia walki z terroryzmem, selektywne zabójstwa, proliferacja dronów

\section{WAR AGAINST TERRORISM AND THE USE OF DRONES}

\begin{abstract}
In recent times there has been a widespread use of the military and other drones (Unmanned Aerial Vehicles) in many fields, both in the military and civilian life. They are frequently used
\end{abstract}


both by the armed forces of many states as well as by the private companies, including the Private Military Companies (PMC). The most controversial issue connected with the use of drones is their deployment in the counterterrorist operations, especially in the so called "targeted killings". Since September 7, in 2000, when a U.S. Predator drone flew over Afghanistan for the first time the drone programme has grown into perhaps the most prominent instrument of U.S. counterterrorism policy. The United States has used drones to support ground troops in Iraq and Afganistan and - particularly under President Barack Obama - to conduct the targeted killings of the leaders of Al-Qaeda and other terrorist groups. Those, last operations stir the public opinion and are the source of many controversies. This article describes the development and technical features (possibilities) of the armed-drones (military drones) and their efficiency in the counterterrorist operations. In the final section of this paper the risk connected with the proliferation of military drones was discussed and assessed.

Keywords: military drones, „death lists”, counterterrorist strategies, targeted killings, proliferation of drones 
